\title{
ANALISIS IMPLEMENTASI PRINSIP KEADILAN DALAM PROSES PENYELESAIAN KEBERATAN PAJAK PADA DIREKTORAT JENDERAL PAJAK
}

\author{
Devi Purnama Sari \\ Institut Ilmu Sosial dan Manajemen STIAMI \\ devi.purnamasari88@yahoo.com
}

\begin{abstract}
Abstrak. Penelitian dilakukan untuk mengetahui apakah asas-asas keadilan telah diterapkan dalam proses penyelesaian Keberatan Pajak, mengetahui hambatan yang ditemui dalam penerapan asas keadilan pada proses Keberatan serta model ideal proses penyelesaian Keberatan Pajak yang adil. Penelitian menggunakan pendekatan kualitatif melalui observasi, studi dokumentasi serta wawancara dengan 10 orang informan yang ahli dan berpengalaman di bidang perpajakan. Hasil penelitian dan interpretasi data menunjukkan bahwa dalam proses Keberatan Pajak oleh DJP belum memenuhi asas keadilan. Adapun hambatan disebabkan entitas beban psikologis petugas pajak yang terbebani tugas penerimaan negara tapi juga harus melaksanakan tugas keadilan dalam memutus Keberatan, pemahaman baik WP maupun fiskus akan peraturan perpajakan, adanya kebijakan "Menolak" internal DJP serta adanya trauma kasus GT dan kriminalisasi fiskus. Sedangkan model ideal lembaga pemroses Keberatan Pajak yang adil dapat dibentuk dengan memisahkan lembaga serta orang-orang yang memutus Keberatan Pajak dari bawah naungan DJP langsung di bawah Menteri Keuangan atau dibuat menjadi Pengadilan Pajak lapis pertama.
\end{abstract}

Kata kunci : keberatan, keadilan, DJP, Pengadilan Pajak

Abstract. This research is performed to analyze if Tax Objection process has fulfilled the equity principle, to find obstacles in fulfilling the equity principle in the Objection process and also to find the ideal model of Tax Objection Process so that equity principle can obtained by the tax payers. The research is performed using qualitative method through observation, documentation study and interviewing 10 experienced informants in taxation. According to the research known that the equity principle has not been fulfilled in the Objection process, these happens because of some obstacles for instance the psychological matter met by the tax authority whom have to fulfill revenue target from tax payers, lack of understanding from both Tax payers and fiscus regarding tax regulations, the DGT internal policy to "Decline" any of Tax Objection request from Tax payers and also traumatic problem of fiscus for having GT-like case and/or criminalization case of tax authority by the DGT. Finally, the ideal model proposal concerning Tax Objection Institution is to shifted from DGT to be directly under the Ministry of Finance or upgraded the institution to be a pure court in the environment of justice power by establishing Tax Court Level I and the existing Tax Court to be a Higher Tax Court.

Key words : objection, equity, DGT, tax court

\section{PENDAHULUAN}

Sehubungan dengan penelitian yang peneliti lakukan, sebelumnya telah ada penelitian yang identik yaitu penelitian $\mathrm{Tb}$. Eddy Mangkuprawira dalam tesisnya yang berjudul Proses Keberatan Pajak sebagai upaya Mencapai Keadilan bagi Wajib Pajak menuju Good Governance Studi Kasus Pada Pengadilan Pajak (2011). Adapun yang membedakan penelitian peneliti dengan penelitian tersebut di atas adalah, penelitian sebelumnya tersebut memfokuskan penelitian pada penerapan asas-asas Good Governance dalam proses keberatan dengan melakukan 
studi kasus pada Pengadilan Pajak. Sedangkan penelitian yang peneliti lakukan sekarang ini adalah berfokus pada analisis implementasi prinsip-prinsip keadilan di dalam penyelesaian keberatan pajak sebagai upaya hukum Wajib Pajak dalam memperoleh keadilan. Peneliti melihat indikator-indikator apakah prinsip keadilan telah diterapkan dalam penyelesaian keberatan oleh Direktorat Jenderal Pajak. Penelitian ini juga akan menjelaskan mengenai model proses penyelesaian keberatan yang ideal terutama dalam mata keadilan bagi Wajib Pajak.

Keadilan adalah salah satu unsur Good Governance yakni equity atau keadilan, yang mana hal tersebut mutlak dipenuhi dalam pemungutan pajak oleh negara kepada masyarakat. Jurnal ini menggunakan pendekatan kualitatif dan paradigma konstruktivisme. Penelitian dilakukan atas Wajib Pajak yang terdaftar pada Direktorat Jenderal Pajak antara bulan Januari sampai dengan Juli 2013. Berbicara mengenai keadilan, filsuf terkenal Aristoteles dalam bukunya Rhetorica (Brotodihardjo, 1989:26) mengatakan, bahwa tugas utama hukum adalah mencapai keadilan.

Sehubungan dengan hal ini, Aristoteles sebagaimana dalam buku Rahardjo (2006) mengatakan bahwa keadilan adalah suatu kebijakan politik yang aturanaturannya menjadi dasar dari peraturan negara dan aturan-aturan ini merupakan tentang apa yang hak. Menurut Aristoteles, orang harus mengendalikan diri dari plonexia, yaitu memperoleh keuntungan bagi diri sendiri dengan cara merebut apa yang merupakan kepunyaan orang lain, atau menolak apa yang seharusnya diberikan kepada orang lain Rawls (2006). Rahardjo (2006), menguraikan bahwa membicarakan hukum adalah membicarakan hubungan antar manusia. Membicarakan hubungan antar manusia adalah membicarakan keadilan. Dengan demikian, setiap pembicaraan mengenai hukum, jelas atau samar-samar, senantiasa merupakan pembicaraan mengenai keadilan pula.

Salah satu perwujudan hukum itu adalah suatu lembaga yang menganut sistem tertentu yang disebut pengadilan. Sedangkan proses dan sistem yang terkait dengan pelaksanaan pengadilan tersebut disebut peradilan yang dalam bahasa Belanda disebut rechtspraak, yang mana dalam bahasa Inggris disebut dengan judicial system. Sistem peradilan yang fair 'adil' dan tidak memihak seperti digariskan di dalam Good Governence (United Nation, 2007:9) yang disponsori oleh Perserikatan Bangsa-Bangsa (PBB) merupakan dambaan rakyat banyak. Hal ini dibuktikan yaitu dengan dibuatnya Undangundang No. 28 tahun 1999 tentang Penyelenggaraan Negara yang Bersih dari KKN.

Sistem perpajakan suatu negara terdiri dari tiga unsur utama (Mansury, 1996:17-23) antara lain tax policy (kebijakan pajak), tax law (hukum pajak) dan tax administration (administrasi pajak). Selanjutnya Mansury merinci Administrasi Pajak menjadi tiga unsur yaitu lembaga, personalia dan prosedur perpajakan. Perwujudan dari tiga unsur tersebut adalah lembaga, personalia dan prosedur. Dalam hal perpajakan, lembaga yang memutuskan Keberatan adalah Direktorat Jenderal Pajak untuk memutuskan permohonan keberatan yang diajukan oleh Wajib Pajak. Keberatan Pajak sebagai salah satu hak Wajib Pajak untuk mendapatkan kepastian hukum dan keamanan setelah adanya pemeriksaan oleh otoritas pajak, menjadi harapan bagi WP untuk memperoleh keadilan serta memperjuangkan haknya jika dirasa hasil pemeriksaan pajak tidak dapat mereka terima.

Keberatan menjadi sangat penting mengingat proses keberatan adalah langkah mendapatkan keadilan yang pertama bagi WP. Proses Keberatan Pajak yang adil dapat meningkatkan kesadaran bagi Wajib Pajak, sehingga dengan sendirinya dapat meningkatkan kepatuhan WP dan pada akhirnya meningkatkan penerimaan negara. Nurmantu (2008) mengutip pesan dari Djajadiningrat bahwa: 
Devi Purnama Sari, Analisis Implementasi Prinsip Keadilan Dalam Proses Penyelesaian....

"pemungutan pajak adalah suatu kekuasaan yang demikian besarnya yang berada di tangan negara, ya bahkan hukumannya dapat diciptakan oleh negara sendiri, justru karena itulah harus disertai dengan pengabdian kepada rakyat, kepada kesejahteraan umum, sehingga menjelma menjadi keadilan."

Hal di atas sejalan dengan perkataan Wallshutzky dalam Wallschutzky di dalam Cedric Sanford, (1993:148-150) bahwa equity of fairness of the tax system, yaitu perlakuan yang sama dan keadilan dalam sistem perpajakan sangat diperlukan dalam pemungutan pajak termasuk dalam proses penyelesaian keberatan. Equity dan fairness adalah unsur utama terkait dengan masalah peradilan. Kategori ini secara eksplisit dan implisit mengandung makna bahwa sistem peradilan perpajakan yang adil dapat meningkatkan kepatuhan perpajakan. Dalam kalimat lain, pendapat Wallschutzky dapat dirumuskan, bahwa makin adil sistem perpajakan, maka makin timbul kepatuhan Wajib Pajak. Sebaliknya, makin tidak adil sistem peradilan perpajakan, maka makin timbul ketidakpatuhan perpajakan dari pihak Wajib Pajak.

Dalam mencari keadilan, salah satu jalan yang harus ditempuh ialah mengusahakan agar upaya pemungutan pajak diselenggarakan secara umum dan merata sesuai kemampuan wajib pajak termasuk dalam memproses Keberatan Pajak. Namun begitu, berdasarkan informasi yang peneliti kutip dari tesis Eddy Mangkuprawira (2011), bahwa pada umumnya Keberatan Wajib Pajak ditolak. Berdasarkan informasi dari para informan yang peneliti dapat saat studi pendahuluan, informan menyatakan bahwa Keputusan Keberatan cenderung diputus dengan keputusan Menolak. Fenomena ini menimbulkan pertanyaan, mengapa Keberatan Wajib Pajak pada umumnya ditolak, hambatan apa yang dihadapi, bagaimana perlakuan sesungguhnya terhadap Keberatan Wajib Pajak, apakah rule of law dan prinsip keadilan diterapkan? Tabel di bawah ini menyajikan Putusan Banding Pengadilan Pajak tahun 2003 sampai 2009.

\section{Tabel 1.1 PUTUSAN BANDING PENGADILAN PAJAK Tahun 2003 s/d 2009}

\begin{tabular}{|r|l|r|r|r|r|r|r|r|r|r|}
\hline No & \multicolumn{1}{|c|}{ Jenis Putusan } & \multicolumn{9}{|c|}{ Jumlah Putusan Pengadilan Pajak } \\
\hline & & 2003 & 2004 & 2005 & 2006 & 2007 & 2008 & 2009 & Jumlah \\
\hline 1 & Membatalkan & 61 & 207 & 637 & 100 & 119 & 114 & 42 & 1280 \\
\hline 2 & Hapus & 4 & 7 & 3 & 5 & 7 & 0 & 13 & 39 \\
\hline 3 & KSL & 519 & 783 & 991 & 863 & 1264 & 1540 & 1890 & 7850 \\
\hline 4 & KSB & 239 & 428 & 495 & 586 & 600 & 736 & 895 & 3979 \\
\hline 5 & TDD & 542 & 549 & 545 & 536 & 843 & 627 & 906 & 4548 \\
\hline 6 & Menolak & 217 & 240 & 304 & 318 & 406 & 751 & 874 & 3110 \\
\hline 7 & Membetulkan & 0 & 0 & 0 & 0 & 0 & 0 & 0 & 0 \\
\hline 8 & Menambah & 3 & 1 & 15 & 2 & 2 & 5 & 30 & 44 \\
\hline 9 & Jumlah & 1585 & 2215 & 2976 & 2410 & 3241 & 3773 & 4650 & 20850 \\
\hline & & & & & & & & \\
\hline 1 & $9-5$ & 1043 & 1666 & 2431 & 1874 & 2398 & 3146 & 3744 & 16302 \\
\hline 2 & $1+3+4$ & 819 & 1418 & 2123 & 1549 & 1983 & 2390 & 2827 & 13109 \\
\hline 3 & $11: 9$ & & & & & & & & \\
\hline 4 & $11: 10$ & & & & & & & & \\
\hline
\end{tabular}

*) Diolah dari Laporan Kinerja Pengadilan Pajak 2009

Catatan : KSL = Mengabulkan seluruhnya

KSB $=$ Mengabulkan sebagian

TDD = Tidak Dapat Diterima

Dari tabel di atas dapat diketahui bahwa dalam kurun waktu 2003 sampai dengan 2009, dalam Putusan Banding, sebesar $80,41 \%$ Putusan Banding yang memenuhi 
persyaratan formal, menerima Permohonan Banding Wajib Pajak atau sama artinya dengan tidak mempertahankan koreksi pemeriksa dan Keputusan Keberatan DJP. Tabel 1 di atas memperlihatkan bahwa Wajib Pajak yang tidak puas atau merasa bahwa Keputusan Keberatan yang diputuskan oleh DJP tidak adil mengajukan permohonan Banding ke Pengadilan Pajak dan ternyata sebagian besar mengabulkan permohonan Banding pemohon Banding (Wajib Pajak). Pertanyaan yang timbul selanjutnya jika dilihat dari sisi pihak petugas pajak adalah apakah petugas betul-betul melaksanakan rule of law (semua berdasarkan hukum) dalam proses penyelesaian keberatan pajak. Sebagai birokrat, apakah petugas pajak telah bertindak secara impersonal Robbins and Barnwell (2002), yaitu tidak mempertimbangkan suku, agama dan asal usul Wajib Pajak yang mengajukan keberatan. Lalu apakah petugas pajak sebagai birokrat telah bertindak secara impartiality Peters (1978) yaitu tidak memihak dalam keputusan keberatan terhadap Wajib Pajak?

Mengenai kebijakan "menolak" ini juga diungkapkan oleh 3 orang Konsultan Pajak yang mewakili Wajib Pajak yang terdaftar pada DJP yang peneliti wawancarai saat penelitian pendahuluan. Mereka mengatakan selama ini menangani keberatan hampir tidak pernah Permohonan Keberatan Pajak dikabulkan oleh Direktorat Jenderal Pajak walaupun telah jelas substansi material atas kasus-kasus tersebut.Wajib Pajak merasa Permohonan Keberatan Pajak mereka tidak benar-benar ditilik, dipelajari dan dipahami oleh Penelaah Keberatan. Hal tersebut semakin Wajib Pajak yakini setelah mereka mengajukan Permohonan Banding ke Pengadilan Pajak atas sengketa pajak mereka dan ternyata dikabulkan oleh Majelis Hakim di Pengadilan Pajak. Hal ini juga diamini oleh Haryadi dari Kamar Dagang dan Industri (Kompas: Maret 2010) bahwa "sedikit sekali petugas yang berani mengabulkan keberatan WP." Sebagaimana diungkakan oleh Hakim Agung di Maryland, Amerika Serikat pada tahun 1819 yang mengatakan "the power to tax involves the power to destroy" yaitu di mana dalam kekuatan untuk memajaki terdapat kekuatan untuk menghancurkan jika tidak adil.

Peneliti ingin mengetahui apakah prinsip-prinsip keadilan telah benar-benar telah diimplementasikan dalam penyelesaian keberatan pajak karena peneliti melihat jika fenomena yang ada dibiarkan tetap terjadi maka tidak akan ada perbaikan pada administrasi pajak dan tidak tercapainya keadilan bagi Wajib Pajak serta terjadinya kesewenang-wenangan kekuasaan dalam memutus permohonan Keberatan Wajib Pajak.

\section{Identifikasi Masalah}

Dari latar belakang penelitian di atas dapat diketahui bahwa sesungguhnya WP mengalami banyak masalah terkait dengan pemenuhan kewajiban perpajakan. Di antara kewajiban yang menjadi permasalahan tersebut antara lain Pemeriksaan Pajak, adanya Surat Ketetapan Pajak, Keberatan Pajak, Banding.

Permasalah WP dalam pengajuan keberatan dimulai dari penerapan peraturan perpajakan oleh petugas pajak.Kemudian apabila terdapat perbedaan penafsiran peraturan perpajakan antara petugas pajak dengan WP.Masalah lainnya yaitu adanya beban psikologis petugas pajak dalam hal ini memutus keberatan oleh penelaah keberatan. Pada satu pihak petugas pajak diharuskan untuk menarik sebesar-besarnya penerimaan negara dari pajak, namun di sisi lain tetap harus memberikan keadilan bagi Wajib Pajak Adanya kriminalisasi petugas pajak jika memberikan keputusan menerima permohonan keberatan pajak WP akan dianggap adanya penyelewengan oleh petugas juga menjadi hambatan WP. Padahal WP telah berkorban waktu, tenaga, pikiran, uang dalam pengajuan keberatan tersebut apalagi jika berdasarkan Surat Ketetapan Pajak jumlah pajak yang harus dibayar besar 
Devi Purnama Sari, Analisis Implementasi Prinsip Keadilan Dalam Proses Penyelesaian....

jumlahnya maka akan mengganggu cash flow usaha WP.

Dalam menuntaskan seluruh masalah yang ada, sesunggunya prinsip keadilan sebagai kunci dalam melaksanakan pungutan pajak adalah yang harus dipegang teguh. Petugas pajak boleh menarik, memaksa dan memperjuangkan untuk menarik pajak dari WP jika memang jelas itu hak negara. Namun jika itu merupakan hak WP maka harus diberikan pula. Keadilan lah yang dirasa menjadi masalah yang sulit untuk digapai dan diraih oleh Wajib Pajak.

\section{Fokus Penelitian}

Secara umum, prinsip keadilan dapat diteliti dari berbagai macam sudut pandang dan permasalahan di dalam perpajakan. Namun melihat keterbatasan peneliti baik dalam hal waktu, biaya dan tenaga, serta agar penelitian dari fokus, maka permasalahan yang akan dibahas oleh peneliti di dalam tesis ini adalah untuk melihat dan menganalisis implementasi prinsip keadilan di dalam proses penyelesaian keberatan pajak oleh DJP.

\section{Rumusan Masalah}

1. Apakah dalam penyelesaian permohonan keberatan pajak yang diajukan oleh Wajib Pajak telah diimplementasikan prinsip-prinsip keadilan?

2. Hambatan-hambatan apa saja yang dihadapi dalam mengimplementasikan asas-asas keadilan dalam penyelesaian proses keberatan?

3. Bagaimanakah model ideal penyelesaian keberatan pajak pada Direktorat Jenderal Pajak yang adil?

\section{Tujuan Penelitian}

1. Untuk menganalisis penerapan asas-asas keadilan dalam proses penyelesaian Keberatan Wajib Pajak oleh Direktorat Jenderal Pajak.

2. Untuk menganalisis hambatan-hambatan apa saja yang dihadapi dalam penerapan asas-asas keadilan dalam proses penyelesaian keberatan Wajib Pajak.
3. Untuk menganalisis model ideal proses penyelesaian keberatan Wajib Pajak oleh Direktorat Jenderal Pajak yang adil.

\section{Kegunaan Penelitian}

1. Kegunaan untuk para akademisi

Hasil penelitian ini diharapkan dapat memberikan sumbangan terhadap konsep dan teori tentang kepatuhan perpajakan, khususnya kategori-kategori yang saling memperkuat dalam peradilan perpajakan.

2. Kegunaan untuk para pengambil kebijakan

Hasil penelitian ini diharapkan dapat memberikan sumbangan kepada para pengambil kebijakan dan keputusan, sehingga dapat diterbitkan berbagai stimulus untuk meningkatkan efektivitas peradilan pajak. Di samping itu, diharapkan adanya kebijakan untuk mengurangi kategori-kategori yang menghambat tercapainya sistem peradilan pajak yang ideal di Indonesia.

3. Kebijakan untuk para praktisi

Hasil penelitian ini diharapkan dapat dimanfaatkan pula oleh para praktisi, baik pejabat pajak, konsultan pajak termasuk juga bagi Wajib Pajak tentang bagaimana menyikapi dan mempraktekkan sistem peradilan pajak yang adil, efektif dan efisien.

\section{KAJIAN LITERATUR Asas Keadilan}

Menurut Adam Smith (2000) perpajakan yang baik adalah perpajakan yang menerapkan empat prinsip perpajakan (the four canon maxims of taxation), yaitu prinsip keadilan (equity), prinsip kepastian (certainty), kecocokan (convenience) dan efisiensi (efficiency). Dalam relevansinya dengan penelitian peneliti, maka peneliti hanya akan membahas mengenai keadilan (equity / equality).

Dalam perkembangannya, akomodasi prinsip keadilan dalam pemungutan pajak adalah adanya perlindungan kepada rakyat dari tindakan pemerintah dalam pemungutan pajak tersebut. Menurut Mar'ie Muhammad 
(Harian Bisnis Indonesia, tanggal 17 Oktober 2005):

“...Tetapi yang lebih penting apakah pembayar pajak dilindungi hakhaknya, jadi harus ada keseimbangan antara kewajiban dan hak sebagai pembayar pajak. Melalui UU, harus ada garansi objektif bahwa petugas pajak tidak boleh berlaku sewenangwenang terhadap pembayar pajak yang telah menyetorkan sebagian penghasilannya kepada Pemerintah tanpa diberikan imbalan apapun secara langsung."

Siahaan (2010) juga memaparkan tiga aspek keadilan yang perlu diperhatikan dalam penerapan pajak, antara lain Keadilan dalam Penyusunan Undang-Undang Pajak, Keadilan dalam Penerapan Ketentuan Perpajakan, Keadilan dalam Penggunaan Uang Pajak. Dalam relevansi dengan penelitian yang peneliti lakukan, keadilan dalam penerapan ketentuan perpajakan adalah yang paling relevan.

Richard A. Musgrave dalam bukunya "The Theory of Public Finance A Study in Public Economy" memberikan sumbangan pemikiran tentang ukuran keadilan dalam perpajakan, yakni untuk mengukur keadilan dalam perpajakan digunakan dua golongan besar, yakni golongan syarat keadilan horizontal dan golongan syarat keadilan vertikal. Suatu pemungutan pajak dikatakan adil secara horizontal, apabila beban pajaknya adalah sama atas semua wajib pajak yang mendapatkan penghasilan yang sama dengan jumlah tanggungan yang sama tanpa membedakan jenis penghasilan atau sumber penghasilan atau biasa disebut equal treatment for the equals ( $\mathrm{R}$ Mansury 1996:10). Sedangkan pemungutan pajak dikatakan adil secara vertikal apabila orangorang dengan tambahan kemampuan ekonomis yang berbeda dikenakan Pajak Penghasilan yang berbeda setara dengan perbedaannya atau biasa disebut dengan unequal treatment for the unequals ( $\mathrm{R}$ Mansury 1996:10).
Tokoh administrasi klasik Max Weber (Robbins, 2001:586) juga telah mengemukakan pendapatnya bahwa pejabat pemerintahan harus mengusung impersonality dan impartiality. Impersonality adalah suatu prinsip Weber yang mengatakan bahwa dalam melaksanakan tugasnya terutama dalam mengambil keputusan, pejabat tidak boleh mempertimbangkan alasan yang bernuansa agama, ras, dan suku. Jadi dalam menentukan seseorang bersalah atau tidak harus berdasarkan undang-undang. Sedangkan impartiality adalah prinsip Weber di mana dalam mengambil keputusan, seharusnya seorang pejabat tidak boleh memihak, baik memihak kepada negara maupun memihak pihak yang lain.

Berperilaku adil bermakna menempatkan sesuatu pada tempatnya dan memberikan yang menjadi haknya, yang didasarkan pada suatu prinsip bahwa semua orang sama kedudukannya di depan hukum. Dengan demikian, tuntutan yang paling mendasar dari keadilan adalah memberikan perlakuan dan memberikan kesempatan yang sama (equity and fairness) kepada setiap orang. Hal ini berarti, keadilan adalah memberikan apa yang menjadi hak bagi setiap orang tanpa membeda-bedakannya.

Impartiality bermakna bahwa dalam memutus suatu perkara, penegak hukum tidak berpihak kepada masing-masing pihak yang berperkara walaupun jika salah satu pihak yang berperkara adalah dibawah nauangan atau instansi yang sama (netral), memberikan kesempatan yang sama untuk mengungkapkan argumentasi, bukti dan lain sebagainya. Bersikap impartiality berarti berlaku jujur dan memperlakukan yang benar adalah benar dan yang salah adalah salah dan tidak berpihak.

\section{Peradilan Administrasi Pajak}

Rochmat Soemitro dalam desertasinya yang berjudul "Peradilan Administrasi Dalam Hukum Pajak di Indonesia" menyatakan bahwa sebagaimana halnya dalam peradilan administrasi umumnya, dalam peradilam 
Devi Purnama Sari, Analisis Implementasi Prinsip Keadilan Dalam Proses Penyelesaian....

administrasi pajakpun dapat diberi arti yang luas, yaitu mencakup:

I. Peradilan administrasi tak murni

Peradilan administrasi tak murni ialah semua peradilan administrasi yang tidak sepenuhnya memiliki syarat suatu peradilan administrasi, umpamanya karena tidak nyata adanya perselisihan, atau badan (pejabat) yang mengadili termasuk salah satu pihak.

Peradilan administrasi tak murni dapat dibedakan menjadi:

a. Ketetapan administrasi murni;

b. Quasi peradilan;

c. Ketetapan semi administrasi;

d. Semi peradilan.

Dalam kaitannya dengan penelitian ini, ciri administrasi yang peneliti bahas adalah quasi peradilan.

Unsur-unsur quasi peradilan adalah:

a. Nyata ada perselisihan antara WP dengan pejabat administrasi;

b. Badan yang memutus perselisihan merupakan bagian dari pejabat administrasi;

c. Ada kewajiban administrasi untuk memberi keputusan;

d. Merupakan penyelesaian perselisihan, akan tetapi dapat dipertimbangkan lagi.

Diantara penerapan asas keadilan adalah adanya lembaga Keberatan Pajak sebagai bagian dari Peradilan Pajak. Pengajuan Keberatan adalah suatu cara yang dilakukan oleh wajib pajak kepada Ditjen Pajak apabila merasa kurang/tidak puas atas suatu ketetapan pajak yang dikenakan kepadanya atau atas pemotongan/pemungutan oleh pihak ketiga. Setiap wajib pajak berhak mengajukan keberatan.

Keberatan diajukan kepada Kepala Kantor Pelayanan Pajak (KPP) di tempat wajib pajak terdaftar dalam jangka waktu 3 bulan sejak diterbitkannya Surat Ketetapan Pajak. Dalam jangka waktu proses keberatan paling lama 12 bulan harus diterbitkan Surat Keputusan Keberatan oleh Direktorat Jenderal Pajak dalam hal ini diwakili oleh Kantor Wilayah.

II. Peradilan administrasi pajak murni Upaya Hukum adalah upaya untuk menyelesaikan sengketa pajak melalui badan peradilan pajak bilamana keputusan melalui upaya administrasi belum dapat diterima oleh WP.Upaya hukum ini dapat dipersamakan dengan "Upaya Peradilan Administrasi Murni" sebagaimana dikemukakan terdahulu, yaitu melalui badan peradilan pajak. Obyek perselisihan pada pengadilan administrasi pajak murni adalah keputusan pejabat perpajakan yang telah bersifat final (ditingkat administrasi) yaitu keputusan mengenai keberatan jika WP belum merasa puas atas hasil keputusan petugas pajak.

\section{Self Assessment System dan Voluntary Compliance}

Berdasarkan teori Norman D. Nowak tentang Sistem Perpajakan Nowak, 1970 dalam (Mansury, 1996:17-23) yang mengatakan bahwa sistem perpajakan yang baik harus ditopang oleh 3 sub sistem yaitu Tax Policy, Tax Law dan Tax Administration. Peneliti memilih untuk menganalisis di bidang Tax Administration, khususnya tentang penerapan atau implementasi dari pelayanan hak-hak perpajakan dan lebih khusus dalam pelayanan hak keberatan pajak dan bagaimana dampaknya terhadap kepatuhan sukarela Wajib Pajak (Voluntary Tax Payer Compliance).

enurut Gunadi, self assessment system dapat meningkatkan kinerja pemerintah dan dengan demikian meningkatkan efisiensi administrasi (Gunadi, 2004:9). Pendapat Gunadi sejalan dengan Gillis (1989) di dalam bukunya yang mengatakan bahwa self assessment dengan tulang punggung voluntary compliance (kepatuhan suka rela) dapat mengurangi personal kontak petugas pajak dengan masyarakat pembayar pajak. Hal ini menurut Gunadi (2004:9) berarti mempersempit kesempatan 
korupsi dan sekaligus meningkatkan Good Governance.

Dari pendapat para pakar perpajakan tersebut maka dapat ditarik kesimpulan bahwa voluntary compliance adalah tulang punggung dari self assessment system. Selain itu, dua determinan kepatuhan lainnya yang penting dan berkaitan dengan penelitian peneliti adalah kualitas pelayanan administrasi pajak kepada masyarakat (Silvani, 1992 dalam Gunadi, 2004:13) dan sistem keberatan dan banding yang efektif dan efisien (Danzig, 1984 dalam Gunadi, 2004:13). Jika kualitas pelayanan administrasi pajak terhadap permohonan keberatan WP baik, antara lain adil serta tidak sewenang-wenang maka bonusnya adalah dapat meningkatkan kepatuhan WP.

\section{Administrasi Perpajakan yang Sehat}

Sebagai sub sistem ketiga dari sistem perpajakan, administrasi perpajakan mempunyai peranan penting dalam melaksanakan undang-undang perpajakan dan mewujudkan penerimaan negara dari sektor perpajakan sehingga dibutuhkan administrasi perpajakan yang sehat.

Untuk mencapai administrasi perpajakan yang sehat, Toshiyuki dalam Gunadi (2004) mensyaratkan 8 kondisi administrasi perpajakan, di antaranya 4 yang paling relevan dengan penelitian peneliti, antara lain:

a. Harus berdasarkan aturan perpajakan yang sah sesuai dengan ketentuan/peraturan perundangundangan dan transparan

b. Harus dapat merealisasikan perpajakan yang sah dan adil sesuai dengan ketentuan peraturan perundang-undangan perpajakan dan menghilangkan kesewenangwenangan (abuse of power), arogansi, dan perilaku yang dipengaruhi kepentingan pribadi baik sosial, politik, maupun ekonomi. c. Harus mampu menyelenggarakan sistem perpajakan yang efektif dan efisien.

Administrasi pajak disebut efektif bila dapat meminimalisir penghindaran, penyelundupan, pengemplangan, dan penyalahgunaan instrumen perpajakan untuk "membobol" uang negara.

d. Harus dapat meningkatkan kepatuhan pembayar pajak. Dalam sistem self assessment, kepatuhan meliputi kemauan dan kesadaran masyarakat untuk mendaftarkan diri untuk memperoleh Nomor Pokok Wajib Pajak (NPW), menyampaikan Surat Pemberitahuan dengan perhitungan yang lengkap dan benar atas segenap objek pajak dan membayar pajak berdasarkan jumlah yang sebenarnya serta tepat waktu.

Kesimpulan dari penjelasan di atas dan relevansinya dengan penelitian ini adalah bahwa sistem administrasi perpajakan yang baik termasuk di dalamnya administrasi penyelesaian keberatan pajak oleh DJP adalah dalam memutuskan keberatan harus berdasarkan ketentuan perpajakan.Jika Wajib Pajak memang benar, maka sudah selayaknyalah permohonannya diterima dan jika salah tidak sesuai dengan peraturan perpajakan maka ditolak.

Karena jika suatu putusan keberatan tidak berdasarkan peraturan perpajakan maka telah terjadi abuse of power (penyalahgunaan kekuasaan) yang bukannya menimbulkan keadilan melainkan menyebabkan Wajib Pajak jadi justru melakukan tax avoidance atau bahkan tax evasion karena mereka merasa untuk apa membantu otoritasi pajak jika Direktorat Jenderal Pajak saja tidak menghormati dan memberikan hakhak mereka dan adil terhadap mereka.

Prinsip-prinsip Good Governance

Lahirnya Good Governance tidak lepas dari peranan PBB (Perserikatan Bangsa- 
Devi Purnama Sari, Analisis Implementasi Prinsip Keadilan Dalam Proses Penyelesaian....

Bangsa) yang antara lain mewajibkan negara-negara penerima bantuan untuk melaksanakan administrasi pemerintahan secara baik, terbuka, dan bertanggung jawab. Dalam paradigma PBB (UN, 2007:7-8), definisi Good Governance disebutkan sebagai berikut:

"...the exercise of political, economic, and administrative authority to manage a nation's affairs. It is the complex mechanism, process, relationship, and institution through which citizens and groups articulate their interests, exercise their rights and obligations and mediate their differences."

Dari kutipan di atas dapat dipahami bahwa Good Governance adalah pelaksanaan kewenangan politik, ekonomi dan administrasi untuk mengatur hal-hal yang terkait dengan tujuan suatu bangsa.Good Governance diakui sebagai suatu mekanisme, proses dan lembaga yang sangat kompleks di mana penduduk dan kelompok-kelompok dalam masyarakat menyampaikan kepentingan, melaksanakan hak dan kewajiban serta memediasi perbedaanperbedaan yang timbul.

United Nation Development Program (UND) menyajikan Sembilan Characteristic of Good Governance (UN, 2007:9), antara lain:

1. Participation

2. Rule of law

3. Transparency

4. Responsiveness

5. Consensus orientation

6. Equity

Adalah suatu kondisi di mana terdapat persamaan derajat dan kesempatan bagi laki-laki dan perempuan di dalam meningkatkan dan mempertahankan taraf hidup dalam arti yang luas. Di dalam penyelesaian keberatan pajak, Direktorat Jenderal harus berimbang dalam menyikapi antara penerimaan dengan Keberatan, di mana alasan penolakan keberatan harus berdasarkan alasan yang jelas dan tidak memihak kepada pemeriksa pajak.

\section{Effectiveness and efficiency}

Adalah suatu kondisi kepemerintahan di mana proses dan lembaga yang menggunakan sumber daya-sumber daya memberikan hasil atau kinerja optimal. Unsur efektif terkait pada tercapainya tujuan, sedangkan unsur efisiensi terkait dengan penggunakan sumber dayasumber daya secara hemat dengan hasil optimal.

Penyelesaian proses keberatan pajak pada kenyataannya memakan waktu lama yaitu 12 bulan sampai dengan keputusan keberatan dikeluarkan. Wajib Pajak harus bolak balik meminjamkan data, membuat laporan serta datang ke kantor Direktorat Jenderal Pajak untuk pembahasan dengan penerimaan. Namun jika memang kebijakan "menolak" lah yang akan selalu keluar, maka Wajib Pajak akan merasa percuma melakukan semua itu karena mereka berpikir akhirnya juga akan ditolak.

Accountability

Adalah suatu kondisi kepemerintahan di mana penggunaan sumber daya-sumber daya dapat dipertanggungjawabkan kepada publik. Karakteristik ini sangat berkaitan dengan pertanggungjawaban penggunaan dana yang berasal dari publik seperti pajak dan bea cukai yang digunakan pemerintah untuk melaksanakan pemerintahan.

Strategic vision

Di tempat lain, Mas'oed (2003:150-151) dalam Panji Santosa (2008:55) menjelaskan bahwa Good Governance adalah cita-cita yang menjadi visi setiap penyelenggara negara di berbagai belahan dunia termasuk Indonesia. Secara sederhana, Good Governance dapat diartikan sebagai prinsip dalam mengatur pemerintahan yang memungkinkan layanan publiknya efisien, sistem pengadilannya bisa diandalkan, dan administrasinya bertanggungjawab pada publik.

\section{Birokrasi yang Kuat dan Sehat}


Pemungutan pajak menurut Hofstra (kartasasmita, 1998), mencengkeram sangat dalam dan terus menerus dalam kehidupan setiap anggota masyarakat, disebabkan oleh cara pemungutan yang sangat kompleks yaitu cengkeraman pemerintah dalam saku masyarakat. Untuk mencegah terjadinya abuse of power dibutuhkan birokrasi yang kuat dan sehat. Atmosudirdjo (1988) mengatakan bahwa birokrasi yang kuat dan sehat adalah tulang puggung administrasi negara yang baik dan faktor terpenting untuk mencapai dan mempertahankan kestabilan politik dan ekonomi. Menurut beliau, birokrasi yang kuat dan sehat harus memenuhi syarat efektivitas, legitimitas, yuridikitas, legalitas, moralitas, bermutu dan efisiensi.

Sehubungan dengan pembahasan tentang Good Governance, peneliti mengambil beberapa penjelasan Atmosudirdjo yang relevan sebagai berikut:
1. Syarat Yuridikitas (rechmatigheid)
2. Syarat Legalitas (wetmatigheid)
3. Syarat Moralitas
4. Syarat Efisiensi

Sepanjang pelaksanaan pemungutan pajak termasuk penerbitan Surat Ketetapan Pajak dan Keputusan Keberatan Pajak yang dilakukan para pejabat publik/penyelenggara negara termasuk Direktorat Jenderal Pajak dengan tidak memenuhi ke-empat syarat yang dikemukakan Atmosudirdjo tersebut di atas, maka telah terjadi abuse of power atau tindakan kesewenang-wenangan.

Rahardjo (2009) mengutip ucapan Ulpian seorang ahli hukum Romawi kuno ternama, yang terkenal dengan ucapannya "Honiste vivere alterum non laedere, suum quique tribuere" yang artinya adalah hiduplah dengan jujur, jangan menyakiti orang lain, berikan kepada setiap orang apa yang menjadi haknya. Apa yang disampaikan Rahardjo harus menjadi pegangan dalam pemenuhan pelayanan hak-hak Wajib Pajak khususnya dalam pelayanan Keberatan Pajak.

\section{Keterbukaan Informasi Publik}

Hak memperoleh informasi merupakan hak asasi manusia dan keterbukaan informasi merupakan salah satu ciri penting negara demokrasi yang menjunjung tinggi kedaulatan rakyat untuk mewujudkan penyelenggaraan negara yang baik. Selanjutnya keterbukaan informasi publik merupakan sarana dalam mengoptimalkan pengawasan publik terhadap penyelenggara negara dan badan publik lainnya. Menurut Gunadi (2004:21), adanya semangat transparansi baik dari administrasi perpajakan, masyarakat pembayar pajak maupun para pihak yang terkait dengan sistem perpajakan dapat membangun transparansi perpajakan dari masyarakat dalam mendorong voluntary compliance. Gunadi (2004:21) di dalam bukunya mengutip perkataan Toshiyuki (2001), berpendapat bahwa kepercayaan publik terhadap administrasi dan sistem perpajakan sebagai pilihan untuk mensejahterakan rakyat menuju "welfare state" merupakan penggerak utama voluntary compliance.

\section{Teori Welfare State dan Konsep Rule of} Law

Ismail (2008) menjelaskan tentang teori welfare state yang berasal dari Otto von Bismark, bahwa:

" negara/pemerintah bertanggungjawab penuh untuk menyediakan semua kebutuhan rakyatnya dan tidak dapat dilimpahkan kepada siapapun. Otto mewacanakan konsep kesejahteraan masyarakat (welfare state) tersebut secara konkret ke dalam bentuk model program kesejahteraan masyarakat bagi pemerintahan modern (the model of modern government social security program).", 
Devi Purnama Sari, Analisis Implementasi Prinsip Keadilan Dalam Proses Penyelesaian....

Ditinjau dari sudut ilmu negara, welfare state diklasifikasikan sebagai salah satu tipe negara, yaitu tipe negara kemakmuran. Pada tipe negara welfare state tersebut, negara mengabdi sepenuhnya kepada masyarakat. Negara sebagai satu-satunya institusi yang berkewajiban menyelenggarakan kemakmuran rakyat. Negara harus aktif menyelenggarakan kemakmuran warganya untuk kepentingan seluruh rakyat. Konsep welfare state ini merupakan perkembangan lanjutan dari konsep rule of law pada negara hukum klasik.

Konsep rule of law dikembangkan oleh Dicey (1959) yang membagi the rule of law dalam 3 unsur, yaitu

"1. Equality before the law, yaitu bahwa setia manusia mempunyai kedudukan hukum yang sama dan mendapat perlakuan yang sama di hadapan hukum

2. Supremation of law, kekuasaan tertinggi terletak pada hukum

3. Constitution bases on human right, yaitu bahwa konstitusi harus mencerminkan hak asasi manusia."

Wade di dalam Hill dan Hupe (2002) berpendapat bahwa konsep rule of law mempunyai 4 aspek, sebagai berikut:

1. Bahwa segala sesuatu harus dilakukan sesuai dengan hukum. Di mana artinya adalah segala perbuatan yang mengakibatkan hak, kewajiban atau kebebasan dari setiap penduduk haruslah dapat ditunjukkan dasar hukumnya. Bahwa pemerintah haruslah bertindak dan berperilaku dalam kerangka hukum dan prinsip yang membatasi tindakan yang didasarkan pada diskresi kekuasaan semata.

2. Bahwa pertikaian atau perselisihan tentang hukum antara penduduk dan penegak hukum haruslah diselesaikan oleh Mahkamah Konstitusi. Mahkamah Konstitusi harus bebas dari pengaruh pihak manapun.

3. Bahwa hukum harus even-handed, artinya harus tidak mengenal dan memandang secara subjektif terhadap salah satu pihak yang berselisih, yang akan mengakibatkan putusan yang diambil akan berat sebelah.

\section{Tridharma Fiskal/Perpajakan}

Setiap organisasi membutuhkan filsafah atau paradigma ataupun pedoman sebagai etika dan moral serta memberi semangat dalam mencapai visi organisasi dan menjalankan misi organisasi. Mansury (1996:25) dan Kartasasmita (1998:114) merumuskan doktrin yang dipakai sebagai pedoman jajaran DJP pada era 1965-an sampai dengan 1983.

Dharma pertama menyatakan supaya pengenaan pajak haruslah sesuai dengan subjeknya. Dharma kedua menyatakan supaya dalam pengenaan pajak harus tepat pada objeknya dan dharma ketiga menyatakan bahwa pengenaan pajak harus tepat pada waktunya. Ketiga dharma tersebut mengandung pesan yang sangat kuat. Dharma pertama yang terkait pada subjek pajak memberi pesan kepada petugas pajak untuk harus hati-hati dalam menentukan subjek pajak.Dharma kedua mengenai objek pajak mengandung pesan yang terpenting. Karena dari penentuan objek pajak timbul kewajiban membayar pajak bagi subjek pajak. Kesalahan, kelalaian atau kesewenang-wenangan dalam menentukan objek pajak yang berujung pada Penghasilan Kena Pajak (dalam Pajak Penghasilan) akan mengakibatkan timbulnya utang pajak yang tidak sesuai dengan penghasilan Wajib Pajak sehingga dapat membebankan Wajib Pajak.

Dharma ketiga mengenai waktu. Ungkapan klasik dalam perpajakan "pay as you earn and pay as you go" serta leaving tax at source adalah ungkaan untuk menghimbau Wajib Pajak sendiri untuk melunasi kewajiban pajaknya jika 
sudah menerima penghasilan. Ungkapan ini juga dapat dilihat dari aspek inisiatif fiskus untuk memungut atau mengenakan pajak. Intinya petugas pajak dalam memungut/menetapkan pajak harus memperhatikan faktor waktu yang tepat. Aspek lain tentang soal waktu adalah terdapatnya ketentuan daluarsa yang dijamin di dalam undang-undang, baik daluarsa penetapan maupun daluarsa penagihan.

\section{METODE PENELITIAN}

Peneliti menggunakan paradigma konstruktivisme sebagaimana dijelaskan Guba dan Lincoln (1985) karena paradigma penelitian ini sesuai dengan pendekatan kualitatif dan peneliti berpendapat bahwa dalam isu penyelesaian keberatan oleh Direktorat Jenderal Pajak (DJP) sebagai bagian dari Peradilan Pajak serta keadilan sulit untuk dicari sebab dan akibatnya.

Kategori-kategori yang terkait dengan isu penyelesaian proses keberatan oleh DJP dan keadilan dalam hasil penelitian ini diharapkan akan saling memperkuat (mutual simultaneous effect). Mutual simultaneous effect itu antara lain kemampuan untuk memahami ketentuan materiil pengetahuan perpajakan akan memperkuat kemampuan untuk memahami ketentuan formal perpajakan dalam penyelesaian keberatan (Peradilan Pajak). Kategori-kategori ini yang disajikan tidak bersifat sebab akibat, melainkan bersifat mutual simultaneous shaping (Guba dan Lincoln, 1985:37), yaitu kategori yang secara bersama-sama saling memperkuat.

Untuk dimensi pendekatan penelitian, dalam penyusunan tesis ini peneliti menggunakan pendekatan kualitatif dengan alasan-alasan sebagaimana telah peneliti jelaskan di dalam sub bab Pendekatan Penelitian dari bab ini.
Dimensi kedua adalah tujuan penggunaan. Terdapat dua dimensi dilihat dari tujuan penggunaan, yaitu bersifat murni (basic, pure research) dan yang kedua adalah bersifat terapan (applied). Dimensi ketiga adalah dimensi tujuan penjelasan. Kajian terhadap data penelitian lapangan akan disajikan secara redaksional serta menggambarkan kategori-kategori yang terkait dengan isu keadilan pada objek penelitian yaitu proses penyelesaian Keberatan Pajak. Karena itu, dimensi di dalam penelitian ini ditinjau dari segi tujuan penjelasan bersifat deskriptif.

Sebagaimana dijelaskan oleh Neuman (2006:31) dikatakan bahwa penelitian deskriptif adalah menjelaskan mengenai gambaran yang mendetail dan menyeluruh mengenai suatu situasi, keadaan sosial dan suatu hubungan. Pada penelitian deskriptif, peneliti memulainya dengan suatu subjek penelitian yang telah didefinisikan dengan jelas kemudian dijelaskan kembali dengan sangat akurat. Penelitian deskriptif berfokus kepada "bagaimana sesuatu terjadi".

Penelitian deskriptif adalah mengeksplorasi suatu masalah atau menjelaskan mengapa sesuatu masalah terjadi? Ada hal apa? Pada penelitian deskriptif akan banyak kegiatan dan teknik mengumpulkan data, yaitu melalui survey, field research, content analysis dan historical-comparative research.

Dimensi keempat adalah dimensi waktu. Neuman membedakan tiga dimensi penelitian yang terkait dengan waktu yaitu cross-sectioned, longitudinal yang terdiri dari panel, time series dan cohort analysis serta case study. Dalam penelitian ini peneliti menerapkan studi kasus dalam arti studi mendalam yang dikaji dari berbagai aspek yang sekaligus sebagai strategi untuk memperoleh data yang bersangkutan dengan penerapan prinsip keadilan dan penyelesaian permohonan keberatan Wajib Pajak oleh Direktorat Jenderal Pajak. 
Devi Purnama Sari, Analisis Implementasi Prinsip Keadilan Dalam Proses Penyelesaian....

Dimensi kelima adalah dimensi pengamatan. Neuman mengelompokkan field research dan comparative historical untuk data kualitatif. Field research adalah tidak berarti secara harfiah penelitian lapangan, tetapi lebih kepada metode dan strategi memformulasikan ide tau topik. Dalam field research pada pendekatan kualitatif, peneliti memulai dengan ide yang longgar, tidak ketat seperti pada pendekatan kuantitafif.

Ide yang longgar tersebut dalam tesis ini adalah proses penyelesaian keberatan oleh Direktorat Jenderal Pajak sebagai bagian dari Peradilan Pajak berdasarkan Rule of law, legal frameworks should fair and enforce impartially (United Nation, 2007:8). Peradilan yang berdasarkan hukum, kerangka kehidupan dan eksistensi hukum yang adil dan tidak memihak akan menimbulkan keadilan. Keadilan dapat meningkatkan kepatuhan yang pada akhirnya akan meningkatkan peningkatan penerimaan pajak.

Kemudian dilanjutkan dengan penelitian kelompok sosial yang akan diteliti atau site penelitian dalam hal ini adalah Direktorat Jenderal Pajak, sebagai bagian dari sistem Peradilan Pajak tempat Wajib Pajak mencari keadilan dalam penyelesaian keberatan.

\section{Penentuan Informan}

Jumlah informan yang dibutuhkan tidak didasarkan pada hitungan statistik, namun berdasarkan pada kejenuhan data yang diperoleh (snowball sampling) sebagaimana dikatakan oleh Guba dan Lincoln (1985:202) bahwa “ informational redundancy, not a statistical confidence level".

Informan yang terpilih berdasarkan purposive sampling di atas akan peneliti sajikan identitasnya untuk mengetahui kemampuan informan sebagai individu yang menguasai informasi yang ditanyakan. Informan berkualifikasi mempunyai pengalaman sebagai Wajib Pajak yang pernah mengajukan permohonan Keberatan Pajak kepada
Direktorat Jenderal Pajak, menjadi pegawai Direktorat Jenderal Pajak lebih dari 25 tahun, Konsultan Pajak yang berpengalaman lebih dari 10 tahun, selain itu terdapat pula informan yang mempunyai pengalaman di bidang peradilan pajak terutama dalam proses penyelesaian keberatan lebih dari 5 tahun. Jumlah informan dalam tesis ini sebanyak 10 orang agar tercapai kejenuhan dalam menjawab pertanyaan.

Kesepuluh orang informan yang menjadi sumber penelitian melalui metode wawancara adalah sebagai berikut:

1. Dra. Irene Mulyati Salaki, tax partner pada KAP Salaki \& Salaki. Memilik jabatan terakhir sebagai tax manager pada KAP. Arthur Andersen dan memiliki pengalaman di bidang perpajakan lebih dari 30 tahun. Selanjutnya disebut Informan 1 (I.1).

2. Cindy Resita, tax supervisor pada KAP Salaki \& Salaki. Berpengalaman pada bidang perpajakan lebih dari 5 tahun. Selanjutnya disebut Informan 2 (I.2).

3. Rinaldy Sudjatina, mantan pejabat pajak. Berpengalaman menjadi kepala KPP Pratama Purwakarta, Kepala Bidang Peninjauan Kembali, Keberatan dan Banding Kanwil DJP Jawa Barat Satu, jabatan terakhir sebelum pension adalah Kepala Bidang P2 Humas Kanwil DJP Riau dan Kepulauan Riau. Selanjutnya disebut Informan 3 (I.3)

4. Tb. Eddy Mangkuprawira, S.H. M.Si., memiliki jabatan terakhir Hakim Pengadilan Pajak. Sebelumnya pernah menjabat sebagai Ka. Sub. Dit Pengamanan Teknis Dit. Perencanaan Penerimaan dan Penagihan, Ka. Inspeksi Pajak Pontianak, Sekretaris Majelis Pertimbangan Pajak, dan dosen Pascasarjana STIAMI dan STPI. Selanjutnya disebut Informan 4 (I.4).

5. Tri Djoko Harjono, pemilik dan pendiri konsultan pajak T.Hardjono. Berpengalaman di bidang pajak lebih 
dari 15 tahun, menjadi dosen pula pada S1 dan D3 STIAMI. Selanjutnya disebut Informan 5 (I.5).

6. Agung Cahyadi, pemilik dan pendiri konsultan pajak Agung Cahyadi. Berpengalaman di bidang perpajakan lebih dari 15 tahun. Selanjutnya disebut Informan 6 (I.6).

7. Muhammad Sholihur Anwar, memiliki konsultan pajak dan berpengalaman di bidang perpajakan lebih dari 5 tahun. Selanjutnya disebut Informan 7 (I.7)

8. Mariani, group tax manager Circle-K. Berpengalaman lebih dari 20 tahun di bidang perpajakan. Selanjutnya disebut Informan 8 (I.8).

9. Soemarso, jabatan terakhir sebagai pemeriksa pajak pada KPP Pratama Jakarta Gambir 2. Berpengalaman di bidang perpajakan lebih dari 10 tahun. Selanjutnya disebut Informan 9 (I.9).

10. Hasto Waluyo, jabatan terakhir sebagai Tax Manager pada perusahaan dan di konsultan pajak, kuasa hukum pada pengadilan pajak, dosen pada STIAMI S1. Berpengalaman di bidang perpajakan lebih dari 15 tahun. Selanjutnya disebut Informan 10 (I.10).

\section{HASIL PENELITIAN DAN PEMBAHASAN}

\section{Analisis dan Interpretasi Hasil Penelitian}

Berdasarkan data yang telah peneliti dapatkan dari observasi, studi dokumentasi tertulis dan hasil wawancara, peneliti akan membagi analisis dan interpretasi hasil penelitian menjadi 3 bagian, sebagai berikut:

1. Penerapan prinsip keadilan di dalam proses penyelesaian keberatan

Berdasarkan hasil analisis seluruh data, secara umum peneliti dapatkan hasil bahwa penerapan prinsip keadilan dalam proses penyelesaian keberatan masih belum ditemui dan belum dirasakan oleh para Wajib Pajak. Padahal hal-hal yang menyangkut hak Wajib Pajak dan kewajiban petugas pajak sebagai pihak yang berkompeten dan profesional yang telah dengan jelas diatur dalam peraturan perpajakan belum terwujud.

Lembaga Keberatan yang seharusnya mampu meminimalisir perselisihan pajak yang muncul sebagai hasil dari pemeriksaan pajak belum dirasakan, yang tampak adalah jika Wajib Pajak ingin mendapatkan keadilan justru memang harus ke Pengadilan Pajak terlebih dahulu. Hak Wajib Pajak untuk mendapatkan keadilan, kesetaran dalam hukum dengan DJP seolah dianiaya. Pada pelaksanaan proses keberatan, aspek formal memang sekarang sudah lebih rapi, sudah dipenuhi oleh DJP walaupun terkadang masih terdapat penerbitan Surat Ketetapan Pajak yang dilaksanakan dengan melewati salah satu prosedur wajib, antara lain closing conference. Hal ini diketahui dari hasil studi dokumen maupun wawancara dengan informan.

Banyaknya Putusan Banding yang membatalkan Keputusan Keberatan justru semakin menguatkan pernyataan ini. Petugas pajak pada lembaga Keberatan mendengarkan dan mencatat argumen serta bukti-bukti dari Wajib Pajak terlihat hanya sekedar basa-basi dan membuang waktu Wajib Pajak 12 bulan untuk penyelesaian keberatan. Seharusnya DJP sebagai yang berwenang untuk memutus keberatan berkomitmen untuk memberikan keadilan dan harus sadar kan Wajib Pajak adalah pihak yang dipungut dan harus membayar pajak. Jangan sampai negara mengambil yang bukan haknya, merampas hak-hak Wajib Pajak karena itu semua termasuk abuse of power (penyalahgunaan wewenang.)

Selain itu, Direktorat Jenderal Pajak juga harus melaksanakan rule of law (semua berdasarkan hukum). Jadi tidak akan ada keputusan keberatan yang keluar karena kebijakan "menolak" semata. Indonesia adalah negara hukum, semua harus berdasarkan hukum termasuk dalam pemungutan pajak yang merupakan 
Devi Purnama Sari, Analisis Implementasi Prinsip Keadilan Dalam Proses Penyelesaian....

sumber penerimaan negara terbesar. Hukum memang harus keras dan tegas dilaksanakan, bukan hanya terhadap Wajib Pajak tapi juga terhadap petugas pajak. Jangan sampai ada anggapan apalagi perkataan dari WP yang menyatakan bahwa lembaga Keberatan hanya membuang-buang waktu dan tempat yang mustahil untuk didapatkan keadilan.

2. Hambatan-hambatan dalam menerapkan prinsip keadilan pada proses penyelesaian keberatan

(a)Adanya Beban psikologi penelaah keberatan dalam memutus keberatan dengan adil.

Pada satu pihak mereka terbebani dengan tugas penerimaan negara dan dilain pihak juga dituntuk untuk bersikap adil dalam memutus Keberatan Pajak. Para penelaah keberatan juga takut dinilai kurang mampu oleh pimpinan jika melakukan tindakan menerima permohonan keberatan WP. Selama para penelaah keberatan masih "dihantui" dan dikejar-kejar tugas penerimaan negara, akan sulit untuk berlaku independen dan tidak berat sebelah.

(b)Pemahaman akan peraturan perpajakan

Hambatan ini dialami baik oleh Wajib Pajak maupun petugas pajak. Dalam mengajukan permohonan Keberatan, WP harus paham betul kewajiban dan hak nya sehingga jangan sampai permohonan keberatan ditolak karena WP belum pernah dengar, tidak tahu, atau tidak pernah diberitahu karena peraturan jika sudah diundangkan, dianggap semua orang telah mengetahuinya.

Selain itu, hal ini juga berlaku bagi penelaah keberatan. Dengan terbukti banyaknya Putusan Banding yang membatalkan Keputusan Keberatan DJP terlihat bahwa dalam memutus Keberatan, DJP asal putus. Diantara faktornya adalah karena pemeriksa pajak tidak memahami kewajibannya mengenai tata cara pemeriksaan pajak sampai menerbitkan Surat Ketetapan Pajak. Apalagi bila ditambah dengan adanya keputustaan mempertahankan Surat Ketetapan Pajak yang diterbitkan KPP walau jelas-jelas nyata salah baik dalam penafsiran peraturan, salah hitung, tidak memenuhi aspek formal maupun analisis bukti.

(c)Adanya kebijakan "Menolak" dari internal DJP

Sesungguhnya adanya kebijakan menolak ini bukanlah suatu kebijakan tertulis. Namun ternyata berdasarkan studi observasi, dokumen dan wawancara yang peneliti lakukan ternyata hal ini telah menjadi rahasia umum. Dengan adanya kebijakan implisit ini, Penelaah Keberatan jadi takut untuk memberikan putusan dan pastinya mengikuti peraturan internal dan perintah atasan.

Mengenai hal ini informan 6 mengatakan bahwa:

"Kalau mendengarkan iya. Memang saya lihat saat diskusi mereka mengerti dan memahami penjelasan WP. Namun entah mengapa ketika final (keputusan keberatan) hasilnya selalu saja menolak".

Informan 7 mengatakan:

"Penelaah mendengarkan penjelasan WP, mereka biasanya menghindari perdebatan. Namun mengenai finalnya, tetap saja diluar kekuasan WP. Dan biasanya penelaah keberatan menolak permohonan keberatan WP."

Sedangkan Informan 4 mengatakan bahwa "seringnya tidak. Penelaah hanya mengikuti hasil pemeriksaan si pemeriksa dan menguatkannya." Jadi dari hasil wawancara dengan 10 informan, 8 orang menyatakan bahwa mayoritas permohonan keberatan mereka pasti ditolak, namun saat diajukan banding beberapa ternyata diterima. Hal ini menunjukkan bahwa seolah ada kebijakan menolak di dalam lembaga keberatan. 
(d)Adanya trauma kasus GT dan kriminalisasi petugas perpajakan

Dengan adanya kasus GT dan kriminalisasi bahwa petugas pajak yang mengurangkan pajak terutang atau sanksi yang diterima WP bahkan sampai menerima permohonan Keberatan Pajak WP dinilai berlaku melanggar hukum dan menimbulkan kerugian bagi negara serta dianggap perilaku kriminal. Padahal petugas pajak harus berpikir pintar, tentunya mereka memiliki LPP, dan jika mereka yakin mereka bertindak sesuai dengan peraturan yang berlaku maka tidak perlu takut. Hal ini sebagaimana dikatakan oleh informan 1:

"Sejak kasus kriminalisasi pajak Maruli dan adanya kasus Gayus, petugas pajak jadi paranoid, jadi ketakutan untuk memutuskan keberatan yaitu jika menerima permohonan keberatan WP akan dipidana.

Informan 4 juga mengatakan hal yang sama:

"... seharusnya petugas pajak kalau benar untuk apa takut. Sanksi administrasi bagi petugas pajak kan kalau dia nyatanyata melanggar ketentuan...."

Hal ini nampak jelas dirasakan oleh para informan yang notabene tidak semuanya hanya sebagai Wajib Pajak biasa, tapi juga ada yang petugas pajak, mantan hakim di pengadilan pajak juga konsultan pajak. Jadi sejak adanya kasus tersebut para penelaah keberatan takut untuk memberikan keputusan menerima permohonan Keberatan WP, takut diusut dan dinyatakan bersalah. Padahal benar dikatakan informan 4, untuk apa takut jika memang tidak bersalah. LPP bisa membuktikan semuanya. Bukti dari WP juga dapat membuktikan keputusan penelaah keberatan.

3. Model ideal lembaga keberatan dan proses penyelesaian di dalamnya

Dari jawab 10 informan, mereka semua berpendapat sama yaitu lembagai
Keberatan tidak perlu dihapus. Lembaga keberatan perlu ada untuk membantu meminimalisir perselisihan pajak serta membantu menyelesaikan perselisihan pajak lebih dini jika memang bisa diselesaikan sebelum ke Pengadilan Pajak. Namun begitu para informan juga percaya, selama lembaga Keberatan masih berada di bawah naungan Direktorat Jenderal Pajak maka akan sulit bahkan mustahil untuk memutus Keberatan Pajak dengan adil karena DJP dan Wajib Pajak adalah pihak yang sama-sama bersengketa. Oleh karenanya, Keberatan Pajak harus diputus oleh badan dan orang-orang yang independen. Hal ini sebagaimana diungkapkan oleh informan 10 bahwa:

"... yang menjadi masalah pada level keberatan adalah petugas pajak yang memproses adalah pegawai DJ yang notabene adalah instansi yang mengalami sengketa, sudah pasti beban berat sebelah ada pada setiap penelaah keberatan dalam memproses keberatan. Agar fungsi tersebut berjalan, seharusnya keberatan diproses oleh instansi yang independen dari DJP.

Pendapat informan 6 sejalan dengan informan 10:

"Ya karena apa yang telah mereka putuskan di KPP memang pasti akan diputuskan kembali oleh penelaah keberatan. Mereka tidak akan mau menjilat ludah sendiri, karena mereka kan di bawah payung yang sama yaitu DJP. Jadi usul saya adalah keberatan pajak harus ada di luar DJP, jadi mereka bisa independen.

Informan 8 berkata:

"Ya, karena kan pemeriksa pajak dan keberatan berada di bawah naungan yang sama yaitu DJP. Jadi selama pihak yang memutus keberatan di bawah DJP juga saya rasa sulit untuk adil."

Jadi dapat peneliti simpulkan bahwa akan jauh lebih baik dan bisa memberikan dampak keadilan jika lembaga pemutus keberatan tidak di bawah naungan DJP langsung agar melihat dan memutus kasus lebih independen seperti halnya Pengadilan 
Devi Purnama Sari, Analisis Implementasi Prinsip Keadilan Dalam Proses Penyelesaian....

Pajak. Hal ini juga bagus untuk psikologis penelaah keberatan sebagaimana peneliti ungkapkan pada poin sebelumnya agar penelaah keberatan tidak terbeban dengan tugas penerimaan negara dalam pengambilan keputusannya. Alasan lain yang menjadikan poin entitas ini menjadi hal yang urgent karena lembaga keberatan sebenarnya penting untuk memberikan keadilan dan mengurangi perselisihan pajak agar tidak berlarut-larut.

Selain itu perbaikan di dalam lembaga keberatan juga perlu dilakukan, antara lain pengembangan soft skill penelaah keberatan mengenai peraturan, business activity dan industrial practice WP sehingga penelaah keberatan tidak kaku dalam memutus suatu Keberatan. Penelaah keberatan harus melihat dari segala sisi, bukti, argumentasi dan hubungannya dengan peraturan perpajakan yang berlaku. Adapun model ideal lembaga keberatan yang adil menurut observasi, studi dokumen dan hasil wawancara dengan para informan adalah Lembaga Keberatan dipertahankan, namun diputus oleh lembaga yang independen, terpisah dari Direktorat Jenderal Pajak. Model ini dapat dibuat dengan membentuk Pengadilan Lapis Pertama yaitu sebelum Pengadilan Pajak yang sudah ada. Sedangkan Pengadilan Pajak yang telah ada menjadi Pengadilan Lapis Kedua atau Pengadilan tinggi. Alternatif lain dari model ini adalah tidak dibentuk Pengadilan Pajak berlapis, hanya saja untuk Keberatan dibentuk badan khusus yang bergerak / bekerja langsung di bawah Kementerian Keuangan namun bukan Direktorat Jenderal Pajak.

Akhirnya, dari seluruh pembahasan mengenai penerapan prinsip keadilan di dalam proses penyelesaian keberatan dan entitas-entitas yang secara simultan saling membentuk keadilan dapat dilihat pada gambar dibawah ini :

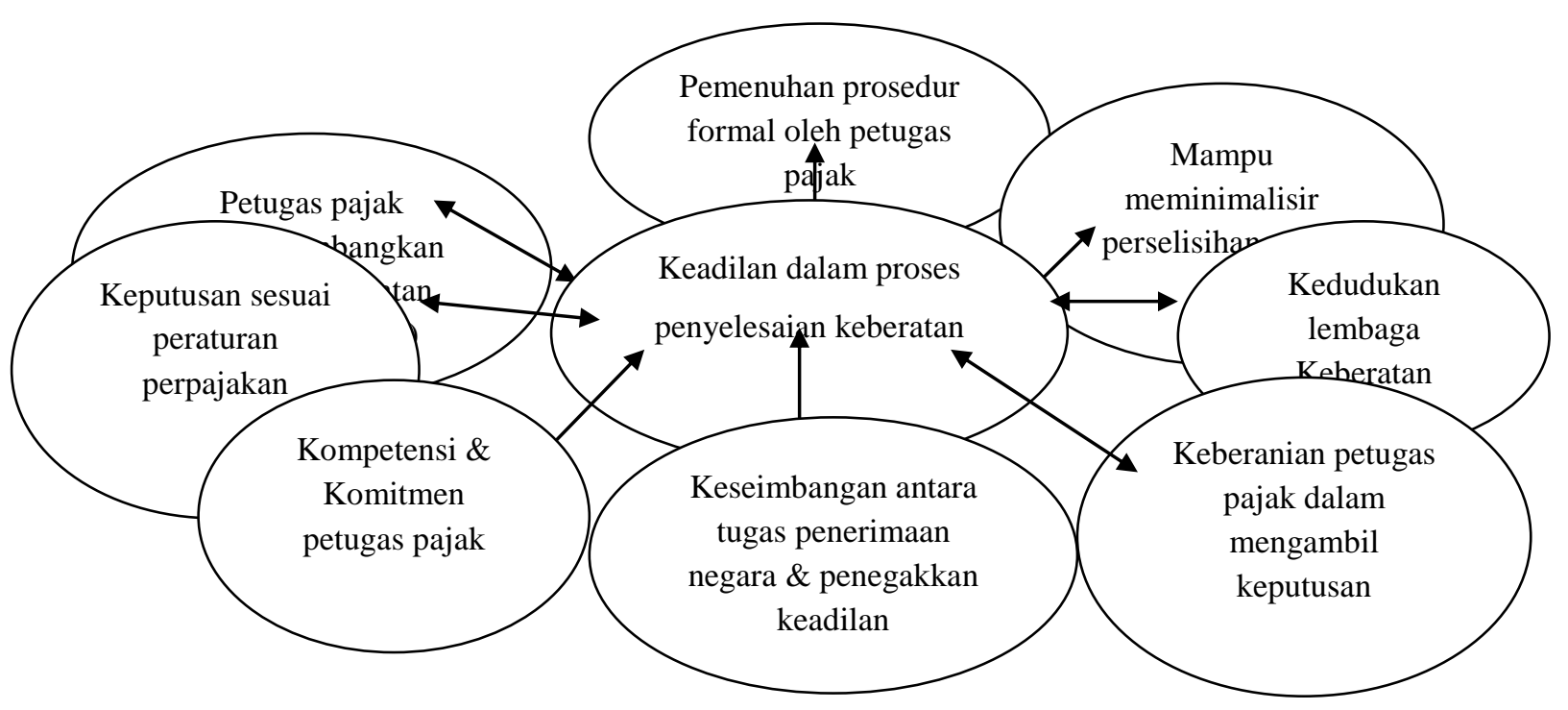

Gambar 4.1 Interpretasi Data Hasil Penelitian

Entitas-Entitas yang Secara Simultan Saling Membentuk

Keadilan dalam Proses Penyelesaian Keberatan

\section{SIMPULAN DAN SARAN}

\section{Simpulan}

1. Berdasarkan hasil penelitian diketahui bahwa asas keadilan di dalam proses penyelesaian Keberatan Pajak masih belum didapatkan oleh Wajib Pajak dan masih belum sepenuhnya diterapkan oleh Direktorat Jenderal Pajak. Asas keadilan 
yang merupakan hal terpenting dan melekat dalam pemungutan pajak masih belum dirasakan. Lembaga Keberatan yang ada sekarang ini pun belum mampu menjembatani serta memenuhi kebutuhan Wajib Pajak sebagai salah satu dari Peradilan Pajak. Dalam banyak kasus, penelaah keberatan hanya mendengarkan, menampung dan menghindari perdebatan mengenai perselisihan pajak yang timbul karena adanya Surat Ketetapan Pajak yang diterbitkan oleh KPP pada saat diskusi penelitian hasil keberatan. Argumen-argumen beserta bukti dan dokumen pendukung yang diajukan oleh WP walaupun telah sesuai dengan peraturan perpajakan masih belum direspon dan ditelaah lebih lanjut oleh Penelaah Keberatan. Berdasarkan hasil wawancara juga disimpulkan bahwa DJP masih belum berimbang dalam menyikapi antara tugas untuk meningkatkan penerimaan negara dari pajak dengan sikap penyelesaian keberatan.

Sikap DJP ini tampak dengan banyaknya Keputusan Keberatan Pajak yang menolak Permohonan Keberatan WP. Alasan penolakan inipun terkadang tanpa dasar hukum yang jelas, cenderung hanya memenuhi tugas penerimaan negara sehingga WP harus berjuang lagi pada proses Banding untuk benar-benar mendapatkan keadilan. Karenanya, Wajib Pajak merasakan sulit sekali mencari keadilan di dalam proses Keberatan Pajak.

2. Penerapan prinsip keadilan yang belum dirasakan oleh para Wajib Pajak saat mengajukan Permohonan Keberatan Pajak timbul karena adanya beberapa hambatan antara lain:

a.) Karena adanya beban psikologis yang dirasakan oleh Para Penelaah Keberatan dan DJP dalam memutus keberatan. Beban psikologis tersebut adalah adanya beban untuk meningkatkan penerimaan negara dari pajak (target pemenuhan penerimaan negara), namun di sisi lain para petugas keberatan juga mengemban tugas untuk memutus keberatan dengan seadil-adilnya dan sebenar-benarnya. Sedangkan faktanya yang dirasakan WP adalah petugas keberatan lebih condong untuk menunaikan tugas penerimaan negara sehingga penelaah banyak menolak permohonan keberatan WP.

b.) Pemahaman Penelaah Keberatan dan Wajib Pajak terhadap peraturan perpajakan serta masih kurangnya law enforcement peraturan perpajakan oleh Penelaah Keberatan.

c.) Adanya kebijakan "menolak" internal DJP, sehingga terdapat banyaknya Permohonan Keberatan Wajib Pajak diputus dengan Keputusan Menolak. Hal ini menjadi rahasia umum bagi Wajib Pajak bahwa Penelaah Keberatan sudah pasti menolak keberatan pajak mereka walaupun sudah memenuhi ketentuan formal dan material. Hal ini seolah adalah instruksi internal dalam kaitannya untuk meningkatkan penerimaan negara dari pajak.

d.) Para petugas pajak trauma dengan kasus kriminalisasi petugas pajak dan korupsi di bidang perpajakan.

\section{B. Saran}

1. Agar dilakukan reformasi terhadap lembaga keberatan, yaitu tidak lagi di bawah naungan Direktorat Jenderal Pajak namun menjadi lembaga yang independen. Adapun pilihannya adalah Permohonan Keberatan Pajak Wajib Pajak diputuskan oleh Lembaga Keberatan yang independen langsung di bawah Kementerian Keuangan ataupun Lembaga Keberatan dibentuk seperti Pengadilan Pajak. Sehingga nantinya akan ada 2 Pengadilan Pajak, yaitu Pengadilan Pajak yang sebelumnya adalah lembaga Keberatan kemudian Pengadilan Pajak 
Devi Purnama Sari, Analisis Implementasi Prinsip Keadilan Dalam Proses Penyelesaian....

yang telah ada sebelumnya menjadi Pengadilan Tinggi (Pengadilan Pajak lapis ke-dua).

2. Berdasarkan pembahasan perlu juga diberikan penataan kembali pejabatpejabat di dalam lembaga keberatan yaitu agar para petugas pajak selain memiliki kemampuan dan pengetahuan yang mendalam mengenai peraturan perpajakan namun juga luas pengetahuan mengenai usaha Wajib Pajak, kegiatan usaha Wajib Pajak dan praktek di lapangan atas usaha milik para Wajib Pajak. Hal ini diperlukan agar petugas pajak dalam memutus dapat melihat bukti / fakta yang nyata terhadap aspek formal maupun material sehingga dapat memutus keberatan pajak dengan adil.

\section{UCAPAN TERIMA KASIH}

Peneliti mengucapkan terima kasih kepada Prof. Dr. Safri Nurmantu, MM selaku pembimbing peneliti, beserta Institut Ilmu Administrasi dan Manajemen STIAMI yang telah memberikan kesempatan dan dukungan bagi peneliti untuk membuat jurnal ilmiah ini serta membantu menelaah dan menerbitkannya. Semoga penelitian ini dapat bermanfaat bagi berbagai kalangan.

\section{DAFTAR PUSTAKA}

Buku :

Abdullah, H. Rozali. 1992. Hukum Acara Peradilan Tata Usaha Negara. Jakarta: Raja Grafindo Perkasa.

Atmosudirdjo, Prajudi. 1988. Hukum Administrasi Negara. Jakarta: Ghalia Indonesia

Brotodihardjo, Santoso. 1989. Pengantar Ilmu Hukum Pajak. Bandung: RafikaAditama.

Caiden, E. Gerald. 1991. Administrative Reform Come of Age. Berlin, New York: Walter de Gruyter.

Denzin, K. Norman danYvonna S. Lincoln. 2004. Handbook of Qualitative Research. London. Sage Publication.
Dicey. 1959. An Introduction to The Study of The Law of Constitution. London: Mac Milon.

Guba, G. Egon dan Yvanna S. Lincoln. 195. Naturalistic Inquiry. Beverly Hill California: Sage Publications.

Gunadi. 2001. Panduan Komprehensif, Pajak Penghasilan. Jakarta: Multi Utama Consulfindo.

Hill, Michael dan Peter Hupe. 2002. Implementing Public Policy, Governance in Theory and in Practice. London: Sage Publications.

Ismail, Tjip. 2008. PengaturanPajak Daerah di Indonesia. Jakarta: Jellow Printing. 1998. Anjing Menggonggong Kafilah Berlalu. Jakarta: (t.p.).

Mansury.1994. Panduan Konsep Utama Pajak Penghasilan Indonesia. Jilid I. Jakarta: Bina Rena Pariwara.

------. 1996. Pajak Penghasilan Lanjutan. Jakarta: Ind-Hill Co.

Marshall, Catherine dan Gretchen B. Rossman. 1989. Designing Qualitative Research. London: Sage Publications.

Musgrave, A. 1976.Public Finance in Theory and Practice.Third Edition. (t.t.): McGraw Hill Kogakusha Ltd.

Newman, Lawrence. 2006. Social Research Methods, Qualitative and Quantitative Approaches. Boston: Allyn and Bacon.

Nowak, Norman. D. 1970. Tax Administration in Theory and Practice with Special Reference to Chile. New York: Preager Publishers.

Patton, Michael Quin. 2000. Qualitative Research \& Evaluation Method. $3^{\text {rd }}$ Edition. London: Sage Publication.

Peters, B. Gay. 197. The Politics of Bureaucracy, A Comparative Perspective. New York: Linguain.

Rahardjo, Satjipto. 2006. IlmuHukum. Bandung. Citra Aditya Bhakti.

------. 2009. Hukum dan Perilaku. Jakarta. Kompas Media Nusantara.

------- 2009. Hukum Progresif Sebuah Sintesa Hukum Indonesia. Yogyakarta: Genta Publishing. 
Jurnal Ilmiah Untuk Mewujudkan Masyarakat Madani

ISSN 2355-309X

Rawls, John. 2006. A Theory of Justice: Teori keadilan Dasar-Dasar Filsafat Politik Untuk Mewujudkan Kesejahteraan Sosial dalam Negara. Yogyakarta:PustakaPelajar.

Robbins, Stephan P. 2001. Organizational Behaviour. $9^{\text {th }}$ Edition. New Jersey. Prentice Hall International Inc.

and Neil Barnwell. 2002. Organizational Theory, Concepts and Cases. New South Wales: Prentice Hall.

Santosa, Panji. 2008. Teori dan Aplikasi Good Governance. Bandung: RafikaAditama.

Siahaan, Marihot P. 2010. Hukum Pajak Material. Yogyakarta: Penerbit Grahallmu.

Soemitro, Rochmat. 1976. Masalah Peradilan Administrsi dalam Hukum Pajak Indonesia. Bandung: Eresco.

Wallschutzky, Ian. 1993. Minimizing Evasion and Avoidance, Lesson from Australia. Bath: Fiscal Publication

\section{Peraturan Perundang-Undangan :}

Republik Indonesia. Undang-Undang Dasar Negara Republik Indonesia Tahun 1945 setelah Amandement I, II, III, IV dan V.

-------. Undang-Undang Nomor 16 Tahun 2009 tentang Perubahan atas UndangUndang Nomor 6 Tahun 1983, Undang-Undang Nomor 9 Tahun 1994, Undang-Undang Nomor 16 Tahun 2000 dan Undang-Undang Nomor 28 Tahun 2007 tentang Ketentuan Umum dan Tata Cara Perpajakan. Lembaran Negara RI Tahun 2009 No. 62. Tambahan Lembaran Negara RI No. 4999.

-------. Undang-Undang Nomor 36 Tahun 2008 tentang Perubahan atas UndangUndang Nomor 7 Tahun 1983, Undang-Undang Nomor 7 Tahun
1991, Undang-Undang Nomor 10 Tahun 1994 dan Undang-Undang Nomor 17 Tahun 2000 tentang Pajak Penghasilan. Lembaran Negara RI Tahun 2008 No. 133. Tambahan Lembaran Negara RI No. 4893.

Undang-Undang Nomor 28 Tahun 1999 tentang Penyelenggaraan Negara yang Bersih dari KKN. Tambahan Lembaran Negara RI No. 3851.

------. Undang-Undang Nomor 14 Tahun 2002 tentang Pengadilan Pajak. Lembaran Negara RI Tahun 2002 No. 27. Tambahan Lembaran Negara RI No. 4189.

-------. Undang-Undang Nomor 37 Tahun 2008 tentang Ombudsman. Tambahan Lembaran Negara RI No. 4899.

Undang-Undang Nomor 5 Tahun 1986 tentang Peradilan Tata Usaha Negara stdt Undang-Undang No. 51 Tahun 2009. Tambahan Lembaran Negara RI No. 5079

\section{Sumber Lain :}

Gunadi. 2004. Reformasi Administrasi Perpajakan Dalam Rangka Kontribusi Menuju Good Governance, Pidato Pengukuhan Guru Besar Luar Biasa Perpajakan FISIP UI. Jakarta: Universitas Indonesia.

Kartasasmita. (Penj.). 1998. Tempat dan Tugas dari Ilmu Pengetahuan Pajak (Pidato H. J. Hofstra pada Penerimaan Jabatan Guru Besar dalam Hukum Pajak Universitas Leiden Belanda 7 Oktober 1996). Belanda: Universitas Leiden.

Mangkuprawira, Eddy. 2011. Tesis: Proses Keberatan Pajak Sebagai Upaya Mencapai Keadilan bagi Wajib Pajak Menuju Good Governance Studi Kasus pada Pengadilan Pajak. Jakarta: STIAMI. 